\title{
Predation Risk and the Importance of Cover for Juvenile Rainbow Trout in Lentic Systems
}

\author{
Roger A. TABOR ${ }^{1}$ \\ Utah Cooperative Fish and Wildlife Research Unit \\ Department of Fisheries and Wildlife, Utah State University \\ Logan, Utah 84322-5210, USA \\ WAYNe A. WurTSBAUGH \\ Department of Fisheries and Wildlife/Ecology Center \\ Utah State University
}

\begin{abstract}
Juvenile rainbow trout Oncorhynchus mykiss stocked in midelevation reservoirs in Utah inhabit shallow nearshore areas and are vulnerable to predation from piscivorous fish and birds. We determined the use and importance of nearshore habitats by (1) measuring habitat selection by, prey availability to, and feeding of juvenile rainbow trout in two reservoirs with populations of predators, and (2) measuring survival and growth rates in the presence and absence of cover in a pond experiment where adult brown trout Salmo trutta were predators. In the reservoirs juvenile rainbow trout (60-120 mm standard length) were abundant in complex inshore habitats but avoided simple habitats such as sand and gravel during the day. At night, however, juvenile rainbow trout in both reservoirs were observed in more exposed areas, and they rested on the bottom. Measurements of gut fullness indicated that juvenile rainbow trout fed actively on large Daphnia spp. during the day but little at night. Because large daphnia were usually more abundant offshore than inshore in both reservoirs, selection of inshore cover is believed to be primarily a response to greater predation risk offshore. In the pond experiment, the presence of brown trout significantly increased mortality of juvenile rainbow trout, decreased their growth rates, and caused them to avoid open-water areas. The presence of cover significantly decreased predation rates but did not affect growth of the juvenile rainbow trout. Fisheries managers should consider augmenting cover in reservoirs and lakes where juvenile trout are stocked to minimize losses of trout to predators.
\end{abstract}

To avoid predation, fish often move to structurally complex habitats where predators cannot forage effectively (Glass 1971; Savino and Stein 1982). Because of this, complex habitats that provide cover are often important nursery areas for the young of many fish species (Hall and Werner 1977; Orth et al. 1984; Lowe-McConnell 1987), and this cover may appreciably increase the survival of juvenile fish (Shulman 1985; Werner and Hall 1988). In lentic systems, juvenile fish often require structurally complex habitats such as aquatic macrophyte beds (Hall and Werner 1977; Mittelbach 1986), inundated vegetation (Aggus and Elliot 1975), and large boulders (Trendall 1988).

Wild populations of lake-dwelling rainbow trout Oncorhynchus mykiss normally have nursery areas in small streams and emigrate to lakes after growing for 1-3 years in the streams (Kwain 1983).

\footnotetext{
${ }^{1}$ Present address: U.S. Fish and Wildlife Service, Western Washington Fishery Resource Office, 2625 Parkmont Lane, Building A, Olympia, Washington 98502.
}

In contrast, juvenile rainbow trout stocked directly into lakes or reservoirs must contend immediately with lacustrine predators. These juvenile fish frequently inhabit the littoral zones until they reach standard lengths (SL) of 100-120 mm, when they move offshore to the limnetic zone (unpublished data).

Although many diurnally active fish in temperate lakes inhabit complex habitats, most of these fish shift from a daytime feeding area near cover to a nighttime resting area on the bottom in relatively exposed locations (Emery 1973; Helfman 1981). Others have a strong affinity for shelter sites at night (Helfman 1981). In many lentic systems, adult brown trout Salmo trutta are nocturnally active (Eriksson 1978; Oswald 1978) and may be important predators of juvenile rainbow trout (Sharpe 1957; Wales and German 1956; our unpublished data). Because of the presence of nocturnal brown trout as well as diurnal predators (e.g., piscivorous birds and adult cutthroat trout Oncorhynchus clarki), juvenile rainbow trout may select both day and night habitats that provide cover. Little is known, however, about their use 
of cover by juvenile rainbow trout in lentic systems or about its importance in reducing predation.

To examine the use of cover by rainbow trout, we measured diurnal and nocturnal habitat selection in two Utah reservoirs that had fish and bird predators. We also monitored the abundance of zooplankton prey at inshore and offshore sites, and we determined temporal variations in feeding to assess the relative importance of different areas and feeding times for foraging. Because the juvenile rainbow trout in the reservoirs selected inshore, complex habitats, we conducted a controlled pond experiment to test how cover and the presence of predators affected survival and growth of the fish.

\section{Study Sites}

We studied the behavior of juvenile rainbow trout in two northern, midelevation Utah reservoirs. East Canyon Reservoir is a 277-hectare impoundment with coordinates $40^{\circ} 54^{\prime} 20^{\prime \prime} \mathrm{N}$, $111^{\circ} 35^{\prime} 20^{\prime \prime} \mathrm{W}$ and an elevation of $1,734 \mathrm{~m}$. It has a mean depth of $23 \mathrm{~m}$ and $16 \mathrm{~km}$ of shoreline. The littoral zone consists primarily of small substrates (1-20 mm in diameter) such as sand and gravel, with some patches of boulders and inundated terrestrial vegetation but few aquatic macrophytes. East Canyon Reservoir is eutrophic, with an abundant population of large Daphnia spp. that provides sufficient forage for juvenile rainbow trout to grow at or near their maximal rate (Marine et al. 1986). The Utah Division of Wildlife Resources stocks the reservoir in early May with 300,000 rainbow trout (mean weight, $6 \mathrm{~g}$; SL, approximately $70 \mathrm{~mm}$ ). Juvenile rainbow trout are preyed on by brown trout, cutthroat trout, and adult rainbow trout (W. A. Wurtsbaugh, unpublished data), as well as by piscivorous birds such as western grebes Aechmophorus occidentalis, Forster's terns Sterna forsteri, and common mergansers Mergus merganser. Redside shiners Richardsonius balteatus, kokanee Oncorhynchus nerka, Utah suckers Catostomus ardens, speckled dace Rhinichthys osculus, and fathead minnows Pimephales promelas are also present in the reservoir.

Mesotrophic Causey Reservoir, the second field site, has an area of 58 hectares, coordinates of $41^{\circ} 17^{\prime} 55^{\prime \prime} \mathrm{N}, 111^{\circ} 35^{\prime} 13^{\prime \prime} \mathrm{W}$ and an elevation of $1,735 \mathrm{~m}$. Its mean depth is $20 \mathrm{~m}$, and its shoreline length is $11.8 \mathrm{~km}$. The littoral zone is similar to that of East Canyon Reservoir except for more medium-sized substrates such as cobble. Because of the steepness of the shore, the littoral zone is generally less extensive than that in East Canyon Reservoir. Zooplankton is abundant, but densities of large daphnia usually are lower than in East Canyon Reservoir. On 6 June 1988, the Utah Division of Wildlife Resources stocked 30,000 rainbow trout averaging $3.2 \mathrm{~g}$ and approximately 60 $\mathrm{mm}$ SL in Causey Reservoir as well as 22,300 larger fish $(8.2 \mathrm{~g}, 77 \mathrm{~mm})$. On 15 May 1989, an additional 61,000 rainbow trout $(5.7 \mathrm{~g}, 70 \mathrm{~mm})$ were stocked. In Causey Reservoir, juvenile rainbow trout are vulnerable to predation from adult brown trout, cutthroat trout, and brook trout $\mathrm{Sal}$ velinus fontinalis. However, unlike at East Canyon Reservoir, few piscivorous birds have been observed at Causey Reservoir. Mottled sculpin Cottus bairdi are also present in Causey Reservoir.

\section{Methods}

Field studies.-Habitat selection by juvenile rainbow trout in nearshore areas was determined through direct observation along shoreline transects. Sampling began 1 week after the fish were introduced to allow them to acclimate and disperse from the stocking site. Transects were surveyed during the next 4 weeks, when the fish ranged from approximately 60 to $120 \mathrm{~mm}$ SL. Because stocked rainbow trout dispersed slowly around the reservoirs (Wurtsbaugh, unpublished data), the transects were confined to within $3 \mathrm{~km}$ of the stocking site, which resulted in $48 \%$ of the shoreline in East Canyon Reservoir and 36\% in Causey Reservoir being surveyed. Within these sampling areas, locations of individual transects were chosen by randomly selecting shoreline sections from a map. At the beginning of the study in 1988, 30-m transects were used in East Canyon Reservoir; later, 100-m transects were used. The length of each transect was measured by a swimmer tied to one end of a 30- or a $100-\mathrm{m}$ rope whose other end was attached to an anchored boat. Forty-three transects (27 in 1988, 16 in 1989) were surveyed in East Canyon Reservoir and 44 (22 in 1988 and 22 in 1989) in Causey Reservoir. Sixty-five percent of the transects were surveyed during day and $35 \%$ at night.

Observations of juvenile rainbow trout and their habitats were made by a swimmer, equipped with snorkel and mask, swimming at the surface 1-6 $\mathrm{m}$ from the shoreline, where the depth varied from 0 to $2.5 \mathrm{~m}$. Preliminary transects with scuba were made at depths of 2.5 and $6 \mathrm{~m}$, but because no juvenile rainbow trout were seen there, we swam only along surface transects in 1988 and 1989. 
Fish beneath the swimmer or between the swimmer and shore could easily be counted unless they were under a rock. Rainbow trout more than 3-4 $\mathrm{m}$ offshore from the swimmer probably were not seen. At night, observations were made with an underwater flashlight. The periphery of the light beam was used to observe juvenile rainbow trout because it did not appear to affect their behavior. Observations consisted of counting fish and noting the closest habitat type to each fish. Observations of schooling activity, feeding activity, and distance from substrate were also recorded.

Habitat characteristics were measured by the swimmer while swimming back to the boat. At every mark on the measuring rope (5-m intervals for 100-m transects, $2-\mathrm{m}$ intervals for $30-\mathrm{m}$ transects) the percentages of different habitat types within a 1-m-diameter circle were estimated. Habitat was classified into seven categories: bedrock, sand-mud (sediment size, $<2 \mathrm{~mm}$ ), gravel (2-20 mm), cobble (20-200 mm), small boulders $(200-500 \mathrm{~mm})$, large boulders $(>500 \mathrm{~mm})$, and inundated vegetation.

Selectivity for each substrate type was calculated with Manly's $\alpha$ (Manly 1974):

$$
\alpha_{i}=\frac{r_{i} / n_{i}}{\sum_{i=1}^{k} r_{i} / n_{i}} ;
$$

$r_{i}$ is the proportion of fish associated with habitat $i, n_{i}$ is the proportion of habitat type $i$ in the environment, and $k$ is the total number of habitat categories. Random use of habitat types occurs when $\alpha_{i}=1 / k$. Significant differences in habitat selection within time periods were tested with a chi-square $\left(\chi^{2}\right)$ goodness-of-fit test (Manly 1974).

To determine if juvenile rainbow trout inhabited nearshore areas because of prey availability, we compared the abundance of daphnia (the principal prey of juvenile rainbow trout in both reservoirs) in nearshore and offshore areas. Daphnia biomass at the offshore sites was a measure of food available to juvenile rainbow trout if they moved to the limnetic zone where cover was low and predation risk high. Food available to juvenile rainbow trout was estimated from the biomass of daphnia $1.0 \mathrm{~mm}$ or more in length, which included $93 \%$ of all daphnids found in juvenile rainbow trout stomachs.

In 1989 zooplankton were collected periodically in both reservoirs for 2 months after juvenile rainbow trout were stocked. Vertical zooplankton tows were made near the stocking sites with a $30-\mathrm{cm}$ - diameter plankton net (153- $\mu \mathrm{m}$ mesh). We calculated daphnia densities by assuming that the net was $100 \%$ efficient, but this may have underestimated actual densities because nets are frequently less than $50 \%$ efficient in eutrophic waters (APHA et al. 1985). Inshore samples were taken from the bottom to the surface at places where the depth was $1.5 \mathrm{~m}$ (3-4 m from shore). This depth represents the approximate mean depth where juvenile rainbow trout were observed during shoreline transects in the littoral zone. In Causey Reservoir, the offshore site was at a depth of $10 \mathrm{~m}$ (approximately $20 \mathrm{~m}$ from shore). In East Canyon Reservoir, offshore sites were at depths of $10 \mathrm{~m}$ and $45 \mathrm{~m}$ (some 20 and $200 \mathrm{~m}$ from shore). Only the upper $5 \mathrm{~m}$ were sampled at the offshore sites because rainbow trout remained primarily in the epilimnion when they moved offshore (our unpublished data). Two or three replicate samples were taken on each date at each site. The first 50 100 daphnia encountered in each sample were measured to the nearest $0.03 \mathrm{~mm}$ from the top of the head to the base of the tail spine with an ocular micrometer. Dry weights $(W, \mathrm{mg})$ of individual daphnids were calculated from lengths $(L, \mathrm{~mm})$ with formulas adapted from McCauley (1984): (1) D. galeata, $\log _{e} W=-4.83+2.53 \log _{e} L$; (2) $D$. schodleri and $D$. pulex, $\log _{e} W=-5.04+2.83$ $\log _{e} L$.

We analyzed diel feeding activity of juvenile rainbow trout to determine how it was related to diurnal and nocturnal habitat use. Juvenile rainbow trout were sampled in 1989 at each reservoir after the fish had been present for 7-10 $\mathrm{d}$ and again after 17-21 d. We sampled 10-12 fish approximately every $3 \mathrm{~h}$ for $24 \mathrm{~h}$. All fish were sampled within $10 \mathrm{~m}$ of shore with a $23-\mathrm{m}$ beach seine, a boat-mounted electrofishing unit, dip nets, or gill nets set for 5-10-min intervals. Within 5-20 min of capture, fish were immobilized with tricaine (MS-222), weighed to the nearest $0.1 \mathrm{~g}$, and measured to the nearest millimeter. Stomachs were removed and placed in $95 \%$ ethyl alcohol. Stomachs were visually inspected to estimate the relative volumetric composition of prey taxa, dried for $18 \mathrm{~h}$ at $60^{\circ} \mathrm{C}$, and weighed to the nearest 0.0001 $\mathrm{g}$ dry weight (DW). A gut-fullness index (GFI; Wurtsbaugh and Li 1985) was calculated as

$$
\mathrm{GFI}=\frac{100,000(\mathrm{DW} \text { gut contents, } \mathrm{mg})}{(\text { fish SL, mm })^{3.05}} .
$$

The exponent 3.05 was empirically derived from the standard length-wet weight regression of ju- 
venile rainbow trout in both reservoirs. Values of GFI observed in the rainbow trout ranged from 0.0 to 11.6 .

Pond experiment. - We tested the effect of predators and cover on the survival, growth, and behavior of juvenile rainbow trout with a controlled pond experiment during June 1988 . The pond was circular with a flat bottom and a maximum depth of $1.4 \mathrm{~m}$. After the pond was drained and all vegetation and debris were removed, the pond was divided with small-mesh netting $(2.5 \mathrm{~m}$ in height; 7-mm-square mesh) into eight equal pie-shaped sections, each with an area of $200 \mathrm{~m}^{2}$. A continuous flow of water was maintained with four inlet pipes placed evenly around the pond. Each section received a flow of approximately $30 \mathrm{~L} / \mathrm{min}$. Surface temperatures in the pond ranged from $15^{\circ} \mathrm{C}$ at the start to $21.5^{\circ} \mathrm{C}$ at the end of the experiment. The bottom temperature was $17^{\circ} \mathrm{C}$ at the end of the experiment. These temperatures were near the preferred temperature range of juvenile rainbow trout in East Canyon Reservoir $\left(16-20^{\circ} \mathrm{C}\right.$; Wurtsbaugh, unpublished data).

Survival, growth, and behavior of juvenile rainbow trout were tested in a $2 \times 2$ factorial design, with the presence and absence of predators and the presence and absence of cover as the treatments. Each treatment was duplicated and assigned randomly to sections of the pond. To simulate complex habitats available in the two reservoirs, three types of cover were used in each section that received cover: (1) 250 wooden stakes (1.0 and $0.5 \mathrm{~m}$ high) placed in a grid $4-6 \mathrm{~cm}$ apart; (2) 30 cement cinder blocks stacked in a loose rectangular configuration; and (3) 12 inverted laundry baskets $\left(0.1 \mathrm{~m}^{3}\right)$ with 4-cm-square mesh. The total area of cover within each pond section was approximately $16 \mathrm{~m}^{2}$. Cover extended from near shore (depth, $0.5 \mathrm{~m}$ ) to a depth of $1.2 \mathrm{~m}$ to ensure that cover was available in areas with suitable temperatures.

Brown trout and juvenile rainbow trout were obtained from hatcheries of the Utah Division of Wildlife Resources. Brown trout (295-420 mm SL) from hatchery brood stock were used as predators; they become piscivorous at lengths greater than 250 mm SL (Scott and Crossman 1973; Garman and Nielsen 1982). For 2 weeks before the experiments began, the brown trout were held in a raceway and fed juvenile rainbow trout.

At the start of the experiment, 180 juvenile rainbow trout were put in each section. Groups of 20-50 fish were counted and stocked sequentially around the pond in each section. To estimate the initial mean weight of the juvenile rainbow trout in the experiment, $20 \%$ of the fish from each group were randomly selected and weighed to the nearest $0.1 \mathrm{~g}$. The estimated mean individual weight of these fish was $4.2 \mathrm{~g}$ (range, 3.0-7.0 g). The following day adult brown trout were weighed (mean weight, $875 \mathrm{~g}$; range, 410-1,680 g; $N=44$ ), and 11 fish were stocked into each of the four sections such that each section received similar sizes of fish. Total predator weight for each section was within $5 \%$ of the other sections. At the end of the experiment all brown trout were recovered and appeared in good condition.

Behavioral observations were made during the main experiment and during a preliminary experiment. We stood 8-12 $\mathrm{m}$ from a study section and observed the fish with binoculars equipped with polarizing filters. The location of juvenile rainbow trout was determined before and after the addition of brown trout predators. The proportions of trout visible within $3 \mathrm{~m}$ of shore (inshore) and greater than $3 \mathrm{~m}$ from shore (offshore) were estimated. Fish offshore in water deeper than approximately $35 \mathrm{~cm}$ could not be observed. For each section, observations were made seven times at various times during daylight.

After $10 \mathrm{~d}$ the pond was partially drained and brown trout were removed with a large-mesh seine. The pond was then drained further until a smallmesh net could be used to remove the majority of juvenile rainbow trout. Finally, the pond was completely drained to collect the remaining fish. The rainbow trout removed from the pond were counted, and 50 from each section were randomly selected and weighed. During the final draining a few juvenile rainbow trout escaped from one section. The total number of fish remaining in this section was estimated by adding the number of juvenile rainbow trout captured with the seine to the number of fish estimated to have avoided the seine net (based on the mean seining efficiency rate of $81 \%$ [range, $64-95 \%$ ] in the other sections).

Growth and mortality were analyzed with a fixed-effects model of a two-way analysis of variance. Growth was analyzed as the percent increase in weight. Mortality was analyzed as the number of juvenile rainbow trout lost during the 11-d experiment.

\section{Results}

\section{Field Studies}

During the day, juvenile rainbow trout that were in the littoral zone of both reservoirs occupied habitat types in a nonrandom pattern (Causey 
A
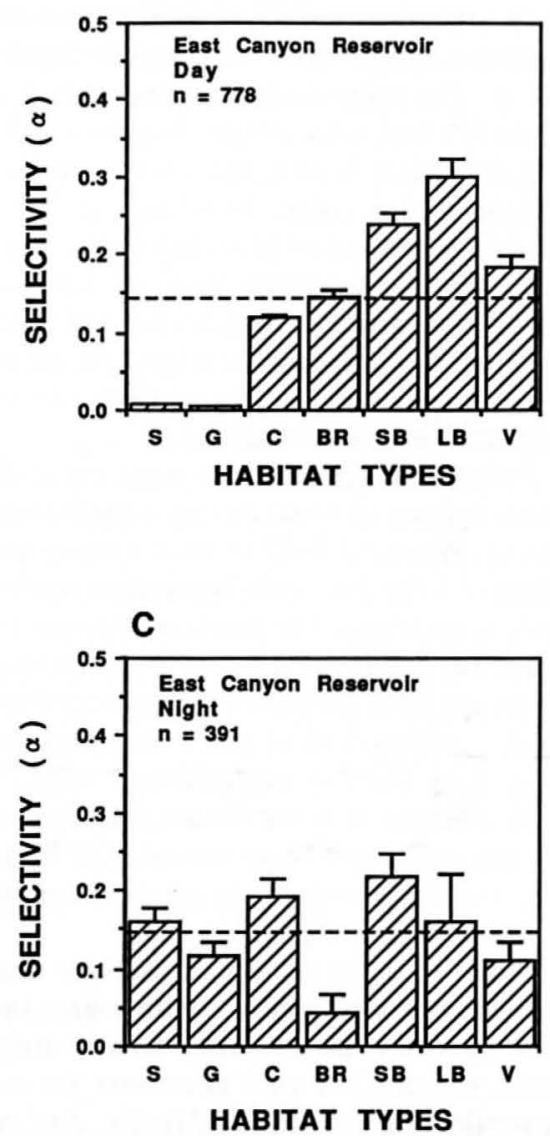
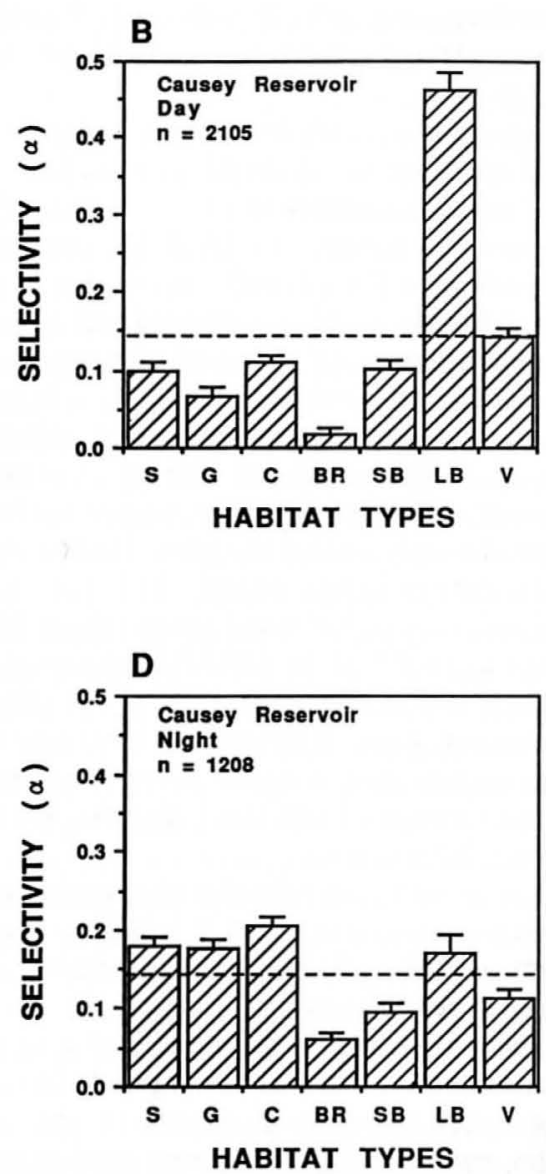

FIGURE 1.-Mean (+SE, vertical line) selectivity values (Manly's $\alpha$ ) for habitat types used by juvenile rainbow trout during the day (A, B) and night (C, D) in East Canyon Reservoir (19-25 May 1988 and 16-31 May 1989) and Causey Reservoir (17 June-12 July 1988 and 31 May-19 June 1989), Utah. The dashed lines indicate the level of selectivity if all habitat types were used at random. Habitat complexity increases from left to right: sand (S); gravel (G); cobble (C); bedrock (BR); small boulders (SB); large boulders (LB); inundated vegetation (V). Number of rainbow trout sampled ( $\mathrm{n}$ ) is also indicated. The actual numbers of fish observed in each habitat and the percentages of each habitat available are given in Tabor (1990).

Reservoir, $\chi^{2}=1,113.9$, $\mathrm{df}=6, P<0.001$; East Canyon Reservoir, $\chi^{2}=892.1, \mathrm{df}=6, P<0.001$ ). They selected the most structurally complex habitats (large boulders, inundated vegetation, and small boulders) and avoided other substrates such as sand and gravel (Figure 1A, B). Although aquatic macrophytes were rare in the reservoirs, and thus poorly sampled, we saw no juvenile rainbow trout in aquatic macrophytes, a finding similar to that of Wasowicz (1991). Although many juvenile rainbow trout were observed closest to sand and gravel substrates, these fish were often near more complex escape cover. Because we recorded the habitat closest to the fish, the actual use of complex habitat may have been underestimated. Al- though boulders and inundated vegetation combined made up approximately $20 \%$ of the nearshore habitat, most of these elements were in small patches scattered along the shore. Juvenile rainbow trout did not use the small patches; rather, they preferred to be on the offshore side of large patches of boulders, inundated willows Salix sp., and fallen trees.

During the day, juvenile rainbow trout were observed from a few centimeters to $2 \mathrm{~m}$ above the substrate. Usually they were observed in schools by themselves or occasionally in schools with redside shiners. Fish near cover were usually in loose aggregations and not strongly oriented to one another. When fish were observed away from cover, 
they were usually in schools of more than 30 fish and appeared to be strongly oriented to one another.

In both reservoirs, nighttime habitat use by juvenile rainbow trout differed from daytime use. The fish did not strongly select structurally complex habitats at night and were often found in exposed areas such as sand, gravel, and cobble (Figure 1C, D). They occupied habitat types at night in a nonrandom pattern (Causey Reservoir, $\chi^{2}=112.3$, df $=6, P<0.001$; East Canyon Reservoir, $\chi^{2}=23.3$, df $\left.=6, P<0.001\right)$. Only bedrock appeared to be strongly avoided, possibly due to its steep slope. Fish observed at night had descended from the water column to within $10 \mathrm{~cm}$ of the substrate. They were easily approached and were motionless or "resting." No feeding or schooling activity was detected. At night, juvenile rainbow trout often were distributed evenly along the transects. For example, in a nighttime survey of Causey Reservoir, we found 290 juvenile rainbow trout distributed along a 200-m shoreline section composed primarily of gravel and cobble except for a 10-m section of large boulders. In contrast, during the day we observed 305 fish along the same section but they were all within the narrow section of large boulders.

Daphnia located offshore were usually larger and accounted for more biomass than daphnia found inshore in both reservoirs (Figure 2). The abundance of daphnia in the littoral zone was low when trout were stocked, but numbers increased greatly within 1-2 weeks. Except for a spring pulse of large daphnia close to shore, mean biomass of daphnia was 3-23 times higher $30 \mathrm{~m}$ offshore than in the nearshore area of Causey Reservoir. Mean daphnia length from late May to mid-July was $0.95 \mathrm{~mm}$ offshore and $0.86 \mathrm{~mm}$ in the inshore areas of Causey Reservoir (Tabor 1990). In East Canyon Reservoir the biomass of large daphnia was often much higher 30-200 m offshore than nearshore (Figure 2). Mean daphnia lengths were $1.29 \mathrm{~mm}$ ( $200-\mathrm{m}$ site), $1.23 \mathrm{~mm}$ (30-m site), and $1.12 \mathrm{~mm}$ (4-m site).

Stomach analyses, as well as underwater observations, demonstrated that juvenile rainbow trout fed actively during the day. During the diel sampling periods, daphnia (primarily D. pulex and $D$. galeata) made up more than $99 \%$ and $96 \%$ of the diet volume of juvenile rainbow trout in East Canyon and Causey reservoirs, respectively. Gut fullness decreased at night, the lowest levels occurring around dawn (Figure 3). In Causey Reservoir, fish began feeding at dawn and gut fullness did not
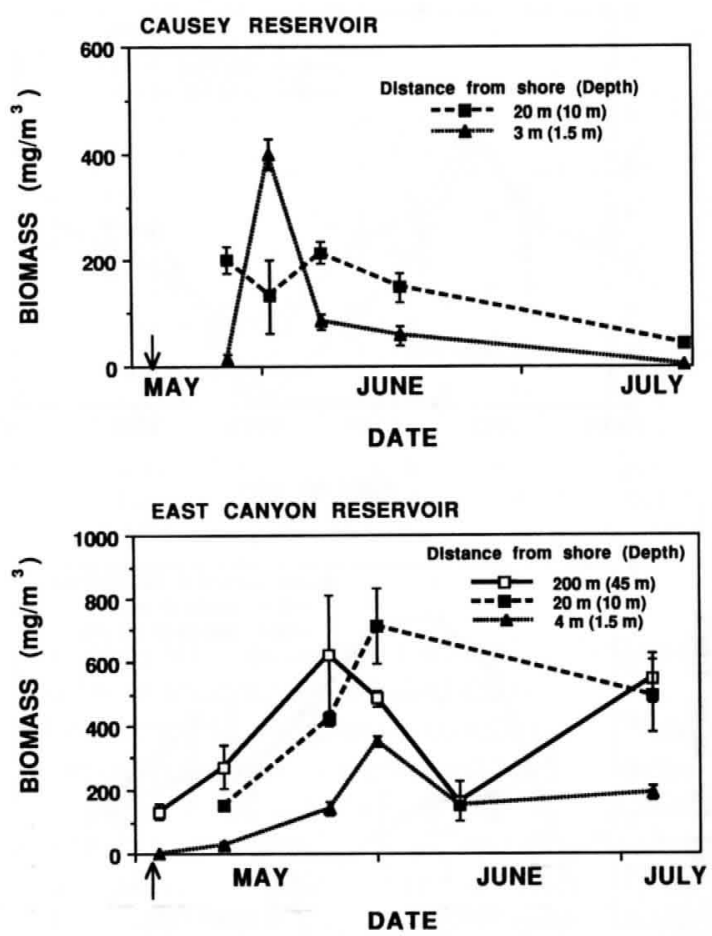

FIGURE 2.-Dry-weight biomasses ( $\pm \mathrm{SE}$, vertical line) of 1-mm or larger daphnia collected at different distances from shore in Causey and East Canyon reservoirs, 1989. Means and standard errors were calculated from two or three vertical net hauls taken at the same site. In Causey Reservoir, the 3-m site was sampled at depths of $0-1.5 \mathrm{~m}$; at the $30-\mathrm{m}$ site, the top $5 \mathrm{~m}$ of the water column was sampled. In East Canyon Reservoir, the 4-m site was sampled at $0-1.5 \mathrm{~m}$; at the $30-\mathrm{m}$ and $200-$ $\mathrm{m}$ sites the top $5 \mathrm{~m}$ of the water column was sampled. Arrows indicate juvenile rainbow trout stocking dates.

peak until late afternoon (1900 hours) on both sampling days (Figure 3). Although gut fullness of East Canyon Reservoir fish varied between the two sampling periods (Figure 3), feeding occurred mostly during the day and at dusk, and gut fullness declined throughout the night. Peaks in gut fullness in East Canyon Reservoir corresponded to wind events that may have moved large offshore daphnia close to shore. Visual observations and zooplankton samples at another East Canyon Reservoir site indicated that large daphnia were abundant close to shore after wind events.

\section{Pond Experiment}

Predaceous brown trout had a highly significant effect on the mortality of juvenile rainbow trout $(F=574.8, \mathrm{df}=1,4, P<0.001)$, which increased approximately sixfold (Figure 4 ). The presence of 

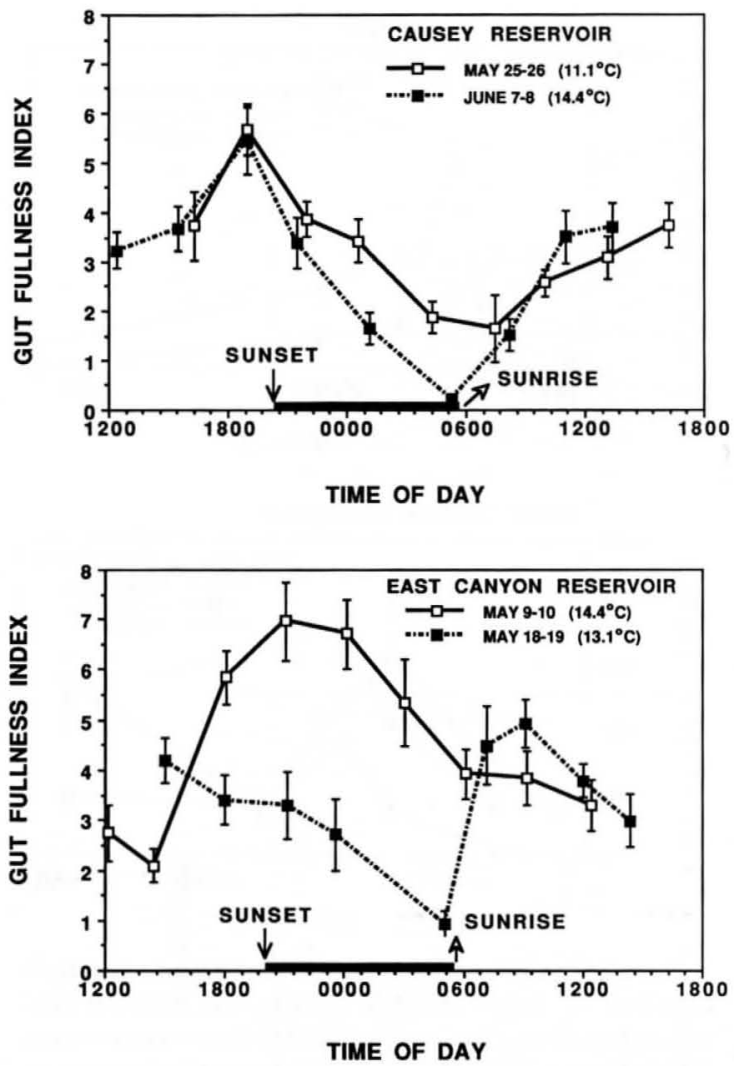

Figure 3.-Diel changes in gut fullness of juvenile rainbow trout in Causey and East Canyon reservoirs during the second and third weeks after stocking in 1989. Time of day is given in daylight saving time. Daytime temperatures at $1-\mathrm{m}$ depth during each period are given in parentheses. Two wind events occurred during the sampling at East Canyon Reservoir: on 9 May from 1700 to 1730 hours and on 18 May from 0900 to 1900 hours. Mean standard lengths of juvenile rainbow trout in Causey Reservoir were $78 \mathrm{~mm}$ on 25-26 May and $89 \mathrm{~mm}$ on 7-8 June. In East Canyon Reservoir, mean lengths were $71 \mathrm{~mm}$ on 9-10 May and $76 \mathrm{~mm}$ on 18-19 May. Error bars indicate \pm 1 SE of the mean.

cover also had a significant effect on the mortality rates of juvenile rainbow trout $(F=24.0, \mathrm{df}=1$, $4, P<0.01)$. For predator treatments the probability of mortality was $34 \%$ lower in sections with cover than in sections without cover. The interaction of cover and predators on trout mortality was nearly significant $(F=5.1$, df $=1,4, P=$ 0.09).

Predation rates in all sections were generally lower than anticipated. Twelve brown trout stomachs (three per section) were examined after the experiment. Three stomachs were empty, four contained snails, six had small amounts of chi-

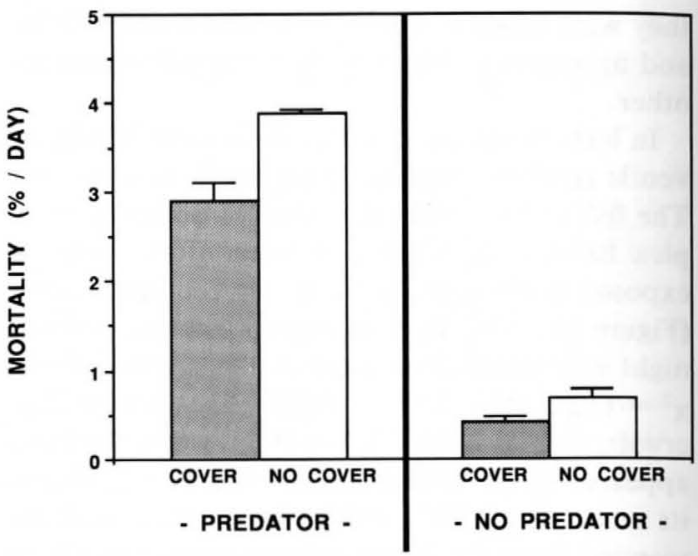

FiguRE 4.-Effects of brown trout (predator) and cover on the mortality of juvenile rainbow trout during an 11-d pond experiment (3-13 June 1988). Mortality is expressed as the percentage of population lost per day (instantaneous mortality rate; Chapman 1978). The upper ranges of duplicate treatments are indicated by the vertical bars.

ronomids, and one had fish remains. Based on mortality rates, each brown trout consumed an average of only 0.41 trout per day or approximately $0.3 \%$ of its body weight. Some cover may have been created at the net margins and lowered predation rates. Although brown trout were observed chasing juvenile rainbow trout on several occasions, they had been habituated to eating pellets at the hatchery, and their limited training with forage fish before the experiment was probably insufficient for them to learn how to effectively pursue and capture prey.

The presence of brown trout predators had a significant negative effect on growth of juvenile rainbow trout $(F=14.2, \mathrm{df}=1,4, P=0.02$; Table $1)$, but the effects of cover and the interaction of cover and predators were not significant $(F=0.3$, $\mathrm{df}=1,4, P=0.59 ; F=0.8, \mathrm{df}=1,4, P=0.41$, respectively). Nevertheless, instantaneous growth rates of juvenile rainbow trout in this experiment were high in all sections (mean, 6.2\%/d). High growth rates presumably resulted from high food abundance. Large numbers of adult chironomids were observed on the water surface, and the few juvenile rainbow trout stomachs we examined at the end of the experiment contained large numbers of adult and larval chironomids.

The daytime visual observations indicated that brown trout had a significant effect on the distribution of juvenile rainbow trout (Wilcoxon ranksum test; $P<0.001)$. In sections without preda- 
TABLE 1.-Initial and final numbers and wet weights (g) of juvenile rainbow trout (prey) and weights (g) of adult brown trout (predators) used in an 11-d predation experiment (3-13 June 1988).

\begin{tabular}{|c|c|c|c|c|c|c|c|c|c|c|}
\hline \multirow[b]{3}{*}{ Treatment } & \multirow{3}{*}{$\begin{array}{l}\text { Repli- } \\
\text { cate }\end{array}$} & & & \multicolumn{7}{|c|}{ Prey } \\
\hline & & \multicolumn{2}{|c|}{ Predator weight } & \multicolumn{2}{|c|}{ Number } & \multicolumn{2}{|c|}{ Initial weight } & \multicolumn{2}{|c|}{ Final weight } & \multirow{2}{*}{$\begin{array}{c}\text { Weight } \\
\text { increase } \\
(\%)\end{array}$} \\
\hline & & Mean & SD & Initial & Final & Mean & SE & Mean & SE & \\
\hline \multirow{2}{*}{$\begin{array}{l}\text { No predators, } \\
\text { cover }\end{array}$} & A & & & 180 & 171 & 4.27 & 0.13 & 9.06 & 0.34 & 112.1 \\
\hline & B & & & 180 & 173 & 4.12 & 0.13 & 8.66 & 0.22 & 115.6 \\
\hline $\begin{array}{l}\text { No predators, } \\
\text { no cover }\end{array}$ & B & & & 180 & 169 & 4.32 & 0.14 & 8.60 & 0.30 & 99.0 \\
\hline \multirow{2}{*}{$\begin{array}{l}\text { Predators, } \\
\text { cover }\end{array}$} & A & 873 & 349 & 180 & 128 & 4.34 & 0.11 & 7.60 & 0.20 & 75.4 \\
\hline & B & 879 & 257 & 180 & 134 & 4.04 & 0.13 & 7.80 & 0.24 & 93.2 \\
\hline \multirow{2}{*}{$\begin{array}{l}\text { Predators, } \\
\text { no cover }\end{array}$} & A & 854 & 325 & 180 & 117 & 3.86 & 0.12 & 6.23 & 0.20 & 79.5 \\
\hline & B & 902 & 325 & 180 & 118 & 4.30 & 0.14 & 8.32 & 0.20 & 93.3 \\
\hline
\end{tabular}

tors, juvenile rainbow trout actively fed at the surface throughout the pond section, and only $22 \%$ $( \pm 1 \mathrm{SE}, 5 \%)$ of the observed fish were inshore. In sections with predators, little feeding activity was detected and $96 \%( \pm 1 \mathrm{SE}, 4 \%)$ of the observed juvenile rainbow trout were inshore in the presence or absence of cover.

\section{Discussion}

Results from the pond experiment demonstrated that structurally complex habitats can be used by juvenile rainbow trout to reduce predation. In East Canyon and Causey reservoirs, juvenile rainbow trout selected habitats during the day that could provide escape cover from predators. Diurnal predators (cutthroat trout and piscivorous birds) were present in both reservoirs and were observed pursuing these fish. Therefore, nearshore cover may be important in reducing predation rates in reservoirs and lakes. An increase in juvenile survival may be expected if large patches of boulders or inundated vegetation are abundant along the shoreline. Other studies have also shown that fish recruitment is related to the availability of nearshore cover (Aggus and Elliot 1975; Wright 1990).

Some juvenile fish inhabit nearshore areas in lentic systems because of prey availability (Whiteside et al. 1985) or temperature preference (Wurtsbaugh et al. 1975; Caulton 1978). In both reservoirs, however, prey was both more abundant and larger offshore than inshore, indicating that the inshore areas were inferior for foraging. Similarly, temperature preferences seem unlikely to have caused the fish to select inshore areas, because midday surface temperatures of offshore and inshore areas differed by less than $1^{\circ} \mathrm{C}$ on the four dates they were measured in East Canyon Reservoir (Wurtsbaugh, unpublished data).

Consequently, we believe that selection of nearshore cover represents a trade-off between foraging offshore to exploit abundant prey and remaining near cover to lower risk of predation. Studies of bluegills Lepomis macrochirus (Werner et al. 1983), blacksmith Chromis punctipinnis (Bray 1981), and wrasse Pseudolabrus celidotus (Jones 1984) have also demonstrated that juvenile fish inhabit areas that do not maximize foraging but provide sufficient cover from predators.

Juvenile rainbow trout may also maximize foraging opportunities and minimize predation risk by making diel inshore-offshore migrations. In East Canyon Reservoir, we have observed rainbow trout migrating $10-50 \mathrm{~m}$ offshore in the morning to feed on abundant large daphnia. After feeding they returned to shoreline areas where risk presumably was reduced (unpublished data).

The change in foraging behavior and the decreased growth rates of juvenile rainbow trout, both due to the presence of brown trout in the pond experiment, suggest that predators may influence rainbow trout food intake. We should caution, however, that the reduced growth of juvenile rainbow trout in the pond sections with predators could have been caused by competition between brown trout and juvenile rainbow trout. We did not document food abundances in the different sections, but the large numbers of chironomids observed in each section indicated high food levels during the experiment. From a controlled predation experiment with juvenile chum salmon Oncorhynchus keta and piscivorous coho salmon O. kisutch, Hargreaves and LeBrasseur (1986) suggested that reduced growth rates of juvenile chum 
salmon were due to intimidation by coho salmon. Reduced food intake due to intimidation by predators has been reported for other fish (Power et al. 1985; Schmitt and Holbrook 1985). Such decreased consumption may reduce growth rates of fish (Werner et al. 1983; Mittelbach 1986). If growth is reduced, juvenile fish will be vulnerable to predators for a longer time and survivorship could be reduced markedly (Werner et al. 1983). In unproductive lentic systems where growth of juvenile rainbow trout is slow and predators are abundant, juvenile rainbow trout may be restricted to the inshore area for extended periods, or they may alter their behavior and accept more risk. Survival of juvenile fish may then be too low to make stocking small rainbow trout of $70 \mathrm{~mm}$ SL economically feasible.

Schooling by juvenile rainbow trout also appeared to be influenced by predators and the proximity of cover. Fish near inundated vegetation and large boulders were often numerous but did not appear to be strongly oriented to one another. In contrast, juvenile rainbow trout above small boulders, cobble, and less complex habitats usually occurred in schools. In the pond experiment, schooling appeared to be more pronounced in sections with predators when cover was absent. Thus, schooling by rainbow trout may indicate the presence of predators or a shortage of complex habitats, as has been shown for other species (Shaw 1978; Savino and Stein 1982; Pitcher 1986).

At night, juvenile rainbow trout in both reservoirs rested in exposed areas in a manner similar to other diurnally active freshwater fish (Emery 1973; Helfman 1981). Emery (1973) suggested that fish occupied exposed positions at night because shelter sites were scarce. In our study sites, however, complex habitats had few fish at night; consequently, there was no apparent shortage of shelter sites. In an alternative explanation, Helfman (1981) proposed that temperate freshwater systems generally lack abundant nocturnal predators; thus, prey have little need to seek cover. Although large predaceous brown trout occurred in both reservoirs, they were not abundant. Brown trout may be able to forage under moonlight and starlight (Oswald 1978; Robinson and Tash 1979). In a preliminary laboratory experiment, juvenile rainbow trout used cover extensively at night when a nocturnally active brown trout predator was present, but they occupied exposed areas at night when a predaceous, diurnally active, adult rainbow trout was present (R. A. Tabor, unpublished data). This suggests that juvenile rainbow trout may use cover extensively when abundant predators are active. Other studies have shown that prey occupy habitats of greater complexity during periods when predators are most active (Hobson 1972; Stein 1979).

For lentic systems in which juvenile rainbow trout are stocked, the augmentation of cover should be considered as a management tool. Inundated vegetation and boulders are particularly valuable habitats. Leaving some inundated trees in new reservoirs may help in this regard. Similarly, Brouha and von Geldern (1979) suggested that planting willows on drawdown zones in western reservoirs would provide cover for juvenile centrarchid fishes. Stocking fish when the water level in the reservoir is at its maximum will usually increase the amount of available cover, because at high water there is usually more inundated vegetation and structural complexity than when the reservoir is drawn down to expose areas where sediments accumulate. For example, in East Canyon Reservoir, inundated vegetation made up $4 \%$ of the nearshore habitat during a low-water year (1988), but it made up $12 \%$ when water levels were higher (1989). Other studies have shown increases in fish recruitment when reservoirs or lakes have risen and inundated shoreline areas (Aggus and Elliot 1975; Bayley 1977).

Although we demonstrated that juvenile rainbow trout use inshore cover and thereby improve their survival when predators are present, we do not know how much cover is necessary to increase survival. For other species, threshold levels of cover may be necessary (Gotceitas and Colgan 1989), and there may be a positive relationship between the amount of cover and recruitment of juvenile fish (Durocher et al. 1984). The recognition that juvenile rainbow trout in lentic systems rely heavily on littoral cover will, we hope, stimulate additional research on microhabitat selection by this species.

\section{Acknowledgments}

We thank R. Taylor and J. Haefner, who assisted with the design of our research and reviewed an earlier draft of the manuscript. G. Cada and two anonymous reviewers provided valuable suggestions for the manuscript. The Utah Division of Wildlife Resources (UDWR) provided funding for the project. J. Leppink of UDWR assisted with stocking requests and acquisition of experimental fish. The Utah Cooperative Fish and Wildlife Research Unit administered the project and provided equipment support. We express our 
appreciation to M. Maughan, who let us use his trout pond. B. Allen, D. Brandt, T. McKay, P. Newby, E. Moreno, and E. He assisted with the field, pond, and laboratory work. J. Moreno and $\mathrm{H}$. Du analyzed the zooplankton samples. G. Workman provided technical assistance with the pond experiment.

\section{References}

Aggus, L. R., and G. V. Elliot. 1975. Effects of cover and food on year-class strength of largemouth bass. Pages 317-322 in R. H. Stroud and H. Clepper, editors. Black bass biology and management. Sport Fishing Institute, Washington, D.C.

APHA (American Public Health Association), American Water Works Association, and Water Pollution Control Federation. 1985. Standard methods for the examination of water and waste-water, 16 th edition. APHA, Washington, D.C.

Bayley, P. B. 1977. Changes in species compositions of the yields and catch per effort during the development of the fishery at Lake Turkana, Kenya. Archiv für Hydrobiologie 79:111-132.

Bray, R. N. 1981. Influence of water currents and zooplankton densities on daily foraging movements of blacksmith, Chromis punctipinnis, a planktivorous reef fish. U.S. National Marine Fisheries Service Fishery Bulletin 78:829-841.

Brouha, P., and C. E. von Geldern, Jr. 1979. Habitat manipulation for centrarchid production in western reservoirs. Pages 11-17 in D. L. Johnson and R. A. Stein, editors. Response of fish to habitat structure in standing water. American Fisheries Society, North Central Division, Special Publication 6, Bethesda, Maryland.

Caulton, M. S. 1978. The importance of habitat temperatures for growth in the tropical cichlid Tilapia rendalli Boulenger. Journal of Fish Biology 13:99112.

Chapman, D. W. 1978. Production. Pages 202-217 in T. B. Bagenal, editor. Methods for assessment of fish production in fresh waters. Blackwell Scientific Publications, Oxford, UK.

Durocher, P. P., W. C. Provine, and J. E. Kraai. 1984. Relationship between abundance of largemouth and submerged vegetation in Texas reservoirs. North American Journal of Fisheries Management 4:8488.

Emery, A. R. 1973. Preliminary comparisons of day and night habits of freshwater fish in Ontario lakes. Journal of the Fisheries Research Board of Canada 30:761-774.

Eriksson, L. O. 1978. Diurnalism versus nocturnalism: dualism with fish individuals. Pages 69-89 in J. E. Thorpe, editor. Rhythmic activity of fish. Academic Press, London.

Garman, G. C., and L. A. Nielsen. 1982. Piscivority by stocked brown trout (Salmo trutta) and its impact on the nongame fish community of Bottom Creek, Virginia. Canadian Journal of Fisheries and Aquatic Sciences 39:862-869.
Glass, N. R. 1971. Computer analysis of predator energetics in the largemouth bass. Pages 325-363 in B. C. Patten, editor. Systems analysis and simulation in ecology, volume 1. Academic Press, New York.

Gotceitas, V., and P. Colgan. 1989. Predator foraging success and habitat complexity: quantitative test of the threshold hypothesis. Oecologia (Berlin) 80:158166.

Hall, D. J., and E. E. Werner. 1977. Seasonal distribution of fishes in the littoral zone of a Michigan lake. Transactions of the American Fisheries Society $106: 545-555$.

Hargreaves, N. B., and R. J. LeBrasseur. 1986. Size selectivity of coho (Oncorhynhus kisutch) preying on juvenile chum (O. keta) salmon. Canadian Journal of Fisheries and Aquatic Sciences 43:581-586.

Helfman, G. S. 1981. Twilight activities and temporal structure in a freshwater fish community. Canadian Journal of Fisheries and Aquatic Sciences 38:14051420.

Hobson, E. S. 1972. Activity of Hawaiian reef fishes during evening and morning transitions between daylight and darkness. U.S. National Marine Fisheries Service Fishery Bulletin 70:715-740.

Jones, G. P. 1984. The influence of habitat and behavioral interactions on the local distribution of the wrasse, Pseudolabrus celidotus. Environmental Biology of Fishes 10:43-58.

Kwain, W. 1983. Downstream migration, population size and feeding of juvenile rainbow trout. Journal of Great Lakes Research 9:52-59.

Lowe-McConnell, R. H. 1987. Ecological studies in tropical fish communities. Cambridge University Press, Cambridge, UK.

Manly, B. F. J. 1974. A model for certain types of selection experiments. Biometrics 30:281-294.

Marine, K. R., W. A. Wurtsbaugh, N. Pace, and K. Christopherson. 1986. Effects of stocking stress on short term survival, long term survival, and growth of rainbow trout in a productive Utah reservoir. Proceedings Bonneville Chapter American Fisheries Society 1986:133-143. Utah Division of Wildlife Resources, Salt Lake City.

McCauley, E. 1984. The estimation of the abundance and biomass of zooplankton in samples. Pages 228265 in J. A. Downing and F. H. Rigler, editors. A manual on methods for assessment of secondary productivity in freshwater. Blackwell Scientific Publications, Oxford, UK.

Mittelbach, G. G. 1986. Predator-mediated habitat use: some consequences for species interactions. Environmental Biology of Fishes 16:159-169.

Orth, R. J., K. L. Heck, Jr., and J. Van Montfrans. 1984. Faunal communities in seagrass beds: a review of the influence of plant structure and prey characteristics on predator-prey relationships. Estuaries 7:339-350.

Oswald, R. L. 1978. The use of telemetry to study light synchronization with feeding and gill ventilation rates in Salmo trutta. Journal of Fish Biology 13: 729-739. 
Pitcher, T. J. 1986. Predators and food are the keys to understanding fish shoals: a review of recent experiments. Naturaliste Canadien (Quebec) 113:225233.

Power, M. E., W. J. Matthews, and A. J. Stewart. 1985. Grazing minnows, piscivorous bass, and stream algae: dynamics of a strong interaction. Ecology 66: 1448-1456.

Robinson, F. W., and J. C. Tash. 1979. Feeding by Arizona trout (Salmo apache) and brown trout (Salmo trutta) at different light intensities. Environmental Biology of Fishes 4:363-368.

Savino, J. F., and R. A. Stein. 1982. Predator-prey interaction between largemouth bass and bluegills as influenced by simulated, submerged vegetation. Transactions of the American Fisheries Society 111: 255-266.

Schmitt, R. J., and S. J. Holbrook. 1985. Patch selection by juvenile black surfperch (Embiotocidae) under variable risk: interactive influence of food quality and structural complexity. Journal of Experimental Marine Biology and Ecology 85:269285.

Scott, W. B., and E. J. Crossman. 1973. Freshwater fishes of Canada. Fisheries Research Board of Canada Bulletin 186.

Sharpe, F. P. 1957. Investigations of the feeding habits of the German brown trout, Salmo trutta, in Shadow Mountain Reservoir. Colorado Cooperative Fisheries Research Unit, Quarterly Report 4:49-63, Fort Collins.

Shaw, E. 1978. Schooling fishes. American Scientist 66:166-175.

Shulman, M. J. 1985. Recruitment of coral reef fishes: effects of distribution of predators and shelter. Ecology 66:1056-1066.

Stein, R. A. 1979. Behavioral response of prey to fish predators. Pages 343-353 in $\mathrm{H}$. Clepper, editor. Predator-prey systems in fisheries management. Sport Fishing Institute, Washington, D.C.

Tabor, R. A. 1990. The importance of cover for juvenile rainbow trout in lentic systems: field obser- vations and experimental studies on predation. Master's thesis. Utah State University, Logan.

Trendall, J. 1988. Recruitment of juvenile mbuna (Pisces: Cichlidae) to experimental rock shelters in Lake Malawi, Africa. Environmental Biology of Fishes 22:117-132.

Wales, J. H., and E. R. German. 1956. Castle Lake investigations - second phase, eastern brook trout. California Fish and Game 42:93-108.

Wasowicz, A. F. 1991. Influence of fish and avian predators upon the trout population of Minersville Reservoir. Master's thesis. Utah State University, Logan.

Werner, E. E., J. F. Gilliam, D. J. Hall, and G. G. Mittelbach. 1983. An experimental test of the effects of predation risk on habitat use in fish. Ecology 64: 1540-1548.

Werner, E. E., and D. J. Hall. 1988. The foraging ratepredation risk tradeoff and ontogenetic habitat shifts in the bluegill sunfish (Lepomis macrochirus). Ecology 69:1352-1366.

Whiteside, M. C., C. M. Swindall, and W. L. Doolittle. 1985. Factors affecting the early life history of yellow perch, Perca flavescens. Environmental Biology of Fishes 12:47-56.

Wright, R. M. 1990. The population biology of pike, Esox lucius L., in two gravel pit lakes, with special reference to early life history. Journal of Fish Biology 36:215-229.

Wurtsbaugh, W. A., R. W. Brocksen, and C. R. Goldman. 1975. Food and distribution of underyearling brook and rainbow trout in Castle Lake, California. Transactions of the American Fisheries Society 104:88-95.

Wurtsbaugh, W. A., and H. Li. 1985. Diel migrations of a zooplanktivorous fish (Menidia beryllina) in relation to the distribution of its prey in a large eutrophic lake. Limnology and Oceanography 30 : 565-576.

Received August 27, 1990 Accepted April 14, 1991 